\title{
GLOBAL JUSTICE
}

NETWORKS

Geographies of transnational solidarity

Paul Routledge and Andrew Cumbers 


\section{Global justice networks}

\section{MANCHESTER

$$
1824
$$

Manchester University Press 
Series editors: SHIRIN M. RAI and WYN GRANT

With the ebbing away of the 'third wave' of democratisation, democratic practice is unfolding and consolidating in different ways. While state based representative democracy remains central to our understanding of the concept, we are also conscious of the importance of social movements, non-governmental organisations and governance institutions. New mechanisms of accountability are being developed, together with new political vocabularies to address these elements in democratic practice. The books published in this series focus on three aspects of democratic practice: analytical and normative democratic theory, including processes by which democratic practice can be explained and achieved; new social and protest movements, especially work with a comparative and international focus; and institutionbuilding and practice, including transformations in democratic institutions in response to social and democratic forces. Their importance arises from the fact that they are concerned with key questions about how power can be more fairly distributed and how people can be empowered to have a greater influence on decisions that affect their lives.

This series takes forward the intellectual project of the earlier MUP series, Perspectives on Democratization.

\section{Already published}

John Anderson Christianity and democratisation: from pious subjects to critical participants

Susan Buckingham and Geraldine Lievesley (eds) In the hands of women: paradigms of citizenship

Bart Cammaerts Mind the gap: internet mediated policy processes beyond the nation state

Francesco Cavatorta The international dimension of the failed Algerian transition: democracy betrayed?

Katherine Fierlbeck Globalizing democracy: power, legitimacy and the interpretation of democratic ideas (2nd edn)

Carina Gunnarson Cultural warfare and trust: fighting the Mafia in Palermo

Jennifer S. Holmes Terrorism and democratic stability revisited (2nd edn)

Anca Pusca Revolution, democratic transition and disillusionment: the case of Romania 


\section{Global justice networks Geographies of transnational solidarity}

Paul Routledge and Andrew Cumbers

Manchester University Press

Manchester and New York

Distributed exclusively in the United States exclusively

by Palgrave Macmillan 
The right of Paul Routledge and Andrew Cumbers to be identified as the author of this work has been asserted by them in accordance with the Copyright, Designs and Patents Act 1988.

Published by Manchester University Press

Oxford Road, Manchester M13 9NR, UK

and Room 400, 175 Fifth Avenue, New York, NY 10010, USA

www.manchesteruniversitypress.co.uk

Distributed in the United States exclusively by

Palgrave, 175 Fifth Avenue, New York,

NY 10010, USA

Distributed exclusively in Canada by

UBC Press, University of British Columbia, 2029 West Mall, Vancouver, BC, Canada V6T 1Z2

British Library Cataloguing-in-Publication Data

A catalogue record for this book is available from the British Library

Library of Congress Cataloging-in-Publication Data applied for

ISBN 9780719076855 hardback

First published 2009

$\begin{array}{llllllllllllllllllll}18 & 17 & 16 & 15 & 14 & 13 & 12 & 11 & 10 & 09 & 10 & 9 & 8 & 7 & 6 & 5 & 4 & 3 & 2 & 1\end{array}$

Typeset

by Florence Production Ltd, Stoodleigh, Devon

Printed in Great Britain

by Biddles Ltd, King's Lynn 